\title{
THE EVOLUTION OF THE IMPORTANCE OF THE TRUE AND FAIR VIEW (TFV) PRINCIPLE. THE CASE OF POLAND
}

\author{
Agnieszka Piechocka-Kałużna \\ Poznań University of Economics and Business, Poznań, Poland \\ e-mail: agnieszka.piechocka@ue.poznan.pl \\ ORCID: 0000-0001-7288-9759 \\ (C) 2018 Agnieszka Piechocka-Kałużna \\ This is an open access article distributed under the Creative Commons Attribution-NonCommercial- \\ -NoDerivs license (http://creativecommons.org/licenses/by-nc-nd/3.0/)
}

DOI: 10.15611/fins.2018.4.06

JEL Classification: M400, M410, M480

\begin{abstract}
The aim of this paper is to analyse matters of truth, which is inherent issue of accounting (and therefore in reporting, as its part), which is reflected in the true and fair principle (TFV). The paper demonstrates the essence of the TFV principle and the evolution of its role and place among the set of qualitative characteristics of financial statements. After examining the changes in the development of the perception of TFV the paper makes an appraisal, gives the author's comments and contribution by providing direct implications for regulators and the setters of standards. With respect to typical limitations regarding behavioural studies, the paper provides practical as well as social implications about understanding of the TFV concept and its effect on both the preparers and users of financial statement.
\end{abstract}

Keywords: true and fair view concept (TFV), truth in accounting, truth in reporting, quality characteristics of financial statements.

\section{Introduction}

In the literature the TFV concept was presented as the parent and overriding accounting assumption/principle. The principles themselves, especially in accounting, mean fundamental truths [Byrne 1937] or general law and rules adopted as a guide to action [May 1937]. According to accounting research studies, accounting reports should disclose that which is necessary to make them not misleading [Sprouse, Moonitz 1962]. It is common to state that accounting has three main underlying principles. These are justice, truth and fairness [Moonitz 1961]. In that sense justice is perceived as equitable treatment to all interests involved in the financial situation covered by the accounts, truth means that accounts must not be made a means of misrepresentation, and fairness reflects the fact that accounting rules and procedures should not serve a special interest. Finally, the accounting general objective, as stated 
in APB 4 [Accounting Principle Board's...], is to provide reliable information about the economic resources and obligations of a business enterprise in order to evaluate its strengths and weaknesses, show its financing and investment, evaluate its ability to meets its commitments and show its resources base for growth.

This paper utilized the literature review, analysis of changes in legal requirements, and comparative analysis. Finally, it defined the trends in TFV perception and evaluated their importance.

This paper aims to systematise, in a chronological order, changes in the perception of TFV over the years as well as to analyse the evolution of TFV recognition in the legal acts on accounting, both in Poland and selected international regulations. Secondly, the paper aims to present and interpret research conducted on those preparing and using financial statements, on truth in reporting and the role of TFV within accounting principles. The author also came to conclusion that we are able to determine an essential change in the perception (in the literature and in legal acts) of TFV's importance. These changes were visible especially in the last decade. Finally, an appraisal was made of the changes, which were already implemented as well as an evaluation of the existing trends in this area. These assessments are then the starting point to indicate normative guidelines, so that the article contributes to the discussion on the directions of the further development of pivotal accounting principles.

The remainder of the paper is organized as follows. Section 2 discusses the background of the TFV concept and explains the meaning of the word 'true'. Sections 3 and 4 present the 'truth' concept in philosophy and its implementation into accounting. Section 5 contains experimental results, summary and conclusions, especially related to emerging markets (including those which are EU members) such as Poland.

\section{2. 'True' and 'fair' perception in accounting}

There are numerous discussions about whether accounting needs any kind of principles, and what the word 'principle' means. While some pretend to define it as some kind of natural truth which helps to present the real picture of an entity in its financial statement [Byrne 1937] or the general rule treated as the basis of conduct or practice [May 1937; Hendriksen, Breda 1992]. Others point out that the word 'principle' itself refers to natural sciences. Accounting arrangements are manmade and there is no one right way of proceeding, therefore they ought to be seen as a convenient way of doing things and should rather be replaced by the word 'standard' [Nolan 1972]. According to Putman, objects of accounting do not exist independently of a conceptual scheme that relates accounting concepts to each other and to their empirical referents and they do not exist independently of the human mind. But this does not mean that such objects are not real [Putnam 1981]. Consequently, he claims that the objects of accounting are part of an economic reality that is socially (intersubjectively) constructed and objectified by the virtue 
of collective intentionality (but only to the extent that such collective intentionality actually exists). Moreover, some contend that there is no room for any kind of principles in accounting since there are no conceptual frameworks in the social sciences [Seidler 1984].

Despite different opinions on the principles in accounting, it is generally accepted that one of the most important assumptions is the true and fair view principle. Before presenting the TFV concept it is worth becoming acquainted with the meaning of the words 'true' and 'fair'. According to dictionary definitions 'true' means as an adjective in agreement with fact/ faithful to another or others, or to a cause or allegiance, genuine, sincere, accurate, correct and as adverb accurately while 'fair' is explained as an adjective according to the rules, complete, thorough and as an adverb according to the rules, squarely [Webster Dictionary]. The most relevant meanings for these two words used so widely in accounting is as 'in agreement with fact' or 'in an accurate manner' for 'true' and 'agreeing with what is thought to be right or acceptable' or 'in a direct and honest way' for 'fair'.

Being aware of TFV, one needs to know what were the roots of implementing that concept into the accounting world. It is absolutely clear that the intention was a willingness to reveal only the pure 'truth' in accounting and financial statements (which are supposed to be its most fruitful element). But there immediately arises a question about a meaning of 'truth'. The answer is not so simple since this problem has been discussed for hundreds of years on the grounds of philosophy and religion. There are several authors who have performed a synthetic presentation of different approaches for 'truth' [Popkin, Stroll 1993; Ajdukiewicz 1983; Ajdukiewicz 2004; Kotarbiński 1961; Tarski 1970] and can be divided into classical and non-classical definitions. It was Aristotle who first formulated classical (per se) definition. His formula was 'To say of what is that it is not, or of what is not that it is, is false, while to say of what is that it is, or of what is not that it is not, is true'. Aristotle's concept is the standard version of the corresponding theory of truth, which says that the truth of a sentence consists in its agreement with reality. On the other hand, there are nonclassic definitions based on relativism [Austin 1950; David 1994; Smid 2014], which generally state that truth depends on some final criterion (more detailed in [Tarski 1933; Tarski 1949; David 1994; Davidson 1990 Kirkham 1992; van Hulle 1997; Piechocka-Kałużna 2014; Küne 2003]). Summarizing the reflections on truth, the most appropriate approach, from the accounting point of view, is based on Popper idea of verisimilitude [Popper 1972; Kueth 2005; Tichy 1974; Rescher 1973] that assumes that one can speak of better or worse approximations to the truth rather than absolute truth itself.

\section{TFV's evolution}

The TFV concept originated in the United Kingdom, considered to be a strong-hold of principles-based accounting and the cradle of the true and fair view override. The UK 
Companies Act of 1948 required that published annual reports should do two things, namely: (a) present a true and fair view of the state of affairs and the results, and (b) follow any relevant detailed legal requirements (of which there were relatively few at that time). Further, it explicitly made clear that if doing (b) was inconsistent with doing (a), then (a) was more important. In other words, (a) can override (b). Thus, if a requirement of the Act would not lead, in a particular situation, to a true and fair view, then that requirement must (not may) not be followed. No definition was or has ever legally been offered of a 'true and fair view' [Alexander, Jermakowicz 2006]. Today one may state that true and fair is not something that is merely a separate add-on to accounting standards [Milanov 2002; Nobes 2000]. Instead the whole essence of standards is to provide for recognition, measurement, presentation and disclosure for specific aspects of financial reporting in a way that reflects economic reality and hence that provides a true and fair view [FRC 2014].

The implementation of the TFV legal requirement in the EU Member States was complicated by differences in their legal and accounting systems, as well as by translation challenges. Article 2(3-5) of the Fourth Directive was transposed into the national legal systems of the EU Member States in different ways.

In the US the TFV concept was not adopted into the regulatory system. It was rather an independent auditor whose report contains an opinion as to whether the financial statements present fairly, in all material respects, an entity's financial position, the results of operations and cash flows in conformity with GAAP. In the 1990s there was a standard [The AICPA SAS 69] that explained the meaning of a fair presentation as a state in which:

- the accounting principles selected and applied have general acceptance;

- the accounting principles are appropriate in the circumstances;

- the financial statements, including the related notes, are informative of matters that may affect their use, understanding, and interpretation;

- the information presented in the financial statements is classified and summarized in a reasonable manner, that is, neither too detailed not too condensed;

- the financial statements reflect the underlying transactions and events in a manner that presents the financial position, results of operations, and cash flows stated within a range of acceptable limits, that is, limits that are reasonable and practicable to attain in financial statements.

The Chairman of the FASB (R. Herz), believes that the US may also support a move towards a more principles-based system, feeling that standards have become too complex and too detailed with too many rules emanating from too many bodies. Therefore, according to D. Tweedie (former IASB chairman) a convergence process is an attempt to develop a single set of high-quality standards that can be used internationally, improving the consistency and quality of financial reporting worldwide.

The most difficult issues that the standard setters have to resolve in the convergence between the US GAAP and IFRS include a consolidation policy and the use of fair value as a measurement attribute [Flower 2004; Schipper 2005]. Some 
authors indicate two other challenges - accounting for financial instruments and performance reporting - which are linked to the use of fair value [Whittington 2005].

It is worth mentioning that currently one may hold disagreement within the International Accounting Standards (IAS) and the International Financial Reporting Standards (IFRS) which means to depart from uncritical, restrictive (and even orthodox) understanding of TFV as an absolute and irrevocable principle. The most obvious manifestation of such a trend is the change of the IAS/IFRS Conceptual Framework, which previously included TFV as an underlying assumption (par. 46) but as of 2010 it was replaced by the fundamental qualitative characteristics, relevance and faithful representation. There is another change that may be perceived in the same vein. The revised conceptual framework does not contain the assumption of prudence. The explanation for this is probably inconsistent with the principle of neutrality. Moreover, there is also materiality that seems to be a significant limitation for reporting under the previous version of Conceptual Framework. Theoretically the Conceptual Framework is not binding on the EU market since it is not implemented by the appropriate EU Commission resolution. However, one must not ignore them as it is IAS / IFRS with their conceptual basis that set new trends within the accounting world. In particular, they show the interesting, from this paper's point of view, and a symptomatic tendency - disappearance of the use of the words 'truth' and 'true'. Was this an intended change in the overall shape of the framework whose general purpose [Nobes, Stadler 2014] is to assist the board (standard setter) when setting accounting standards? The paper highlights the importance of the so-called qualitative characteristics of financial statements. Besides TFV, the International Financial Reporting Standards (IFRS) mention utility, relevance and faithful representation. This was done, in particular, looking through the prism of the development of their location in the conceptual framework for the IFRS regulations and Polish Accounting Act.

Wherever and how frameworks were implemented, there still remains the unanswered question about truth and its reflection in financial reporting. Therefore the author formulated the following hypothesis:

H: There is no truth in financial reporting due to the existence of the TFV principle and its unclear application.

The question that first arises is how to define 'truth' in financial reporting. The truth in accounting is defined variously and frequently indirectly. Namely, it is often characterized by employing more or less corresponding terms. According to the US FASB's Statement of Accounting Concepts No. 2 [FASB, 1980], representational faithfulness is the 'correspondence or agreement between a measure or description and the phenomenon that it purports to represent'. According to the EU approach it is important to note that there are three possible views concerning the true and fair concept. These are (1) it has no meaning, and no effective existence, (2) it is important, as a catch-all addition to detailed regulations and (3) it is important as 
an addition to, and if necessary an overriding alternative to, detailed regulation [Alexander, Jermakowicz 2006].

Since in the case of the TFV concept it is so important to strive for the most accurate reflection of reality, in cases of defining truth in accounting one may use Popper's theory, who stated that there are no general criteria by which we can recognize truth - except perhaps tautological truth - there are something like criteria of progress towards the truth [Popper 1972].

The process of the implementation of the TFV concept into the accounting environment depends largely on the type of the accounting regulatory framework. Generally it is common to divide these systems as principle-based and rule-based accounting. Principles-based accounting is used as a conceptual basis for accountants. A simple set of key objectives are set out to ensure good reporting. Common examples are provided as guidance and explain the objectives. Although some rules are unavoidable, the guidelines or rules set are not meant to be used for every situation. The fundamental advantage of principles-based accounting is that its broad guidelines can be practical for a variety of circumstances. Precise requirements can sometimes compel managers to manipulate the statements to fit what is compulsory. The problem with principles-based guidelines is that the lack of guidelines can produce unreliable and inconsistent information that makes it difficult to compare one organization to another. On the other hand, rules-based accounting is basically a list of detailed rules that must be followed when preparing financial statements. Many accountants favour the prospect of using rules-based standards, because in the absence of rules they could be brought to court if their judgments of the financial statements were incorrect. When there are strict rules that need to be followed, the possibility of lawsuits is diminished. Having a set of rules can increase accuracy and reduce the ambiguity, which can trigger aggressive reporting decisions by management. The complexity of rules, however, can cause unnecessary complexity in the preparation of financial statements [Alexander, Jermakowicz 2006].

To sum up, one may say that the TFV concept is most important under the IASB and EU legal requirements. While in the US, a fair presentation achieved exclusively through adherence to GAAP and TFV override is not applicable. Therefore historically, countries that adopted IFRS, including the EU Member States, are perceived as more principle-based, while the US was rather identified as following rule-based systems. Besides, the implementation of the new EU Directive imposes the TFV override on European markets.

Based on the studies on IAS / IFRS which became a requirement for EU entities, there still exists the opposite trend - which means departure from TFV. Having in mind the revised IFRB Conceptual Framework, one needs to observe the noticeable shift from TFV towards utility that is defined by 'relevance' and 'faithful representation'. In other words, it is usefulness that is the main objective of a financial statement and everything else (even including truth?) must be subordinated to that goal. Therefore replacing TFV by relevance may result in misinterpreting the economic phenomena presented in the reports. 


\section{Methodology description and results}

To test the hypothesis as stated above the author performed an experimental research that comprised of questionnaires, individual intensive interviews, directed interviews, and made telephone calls which is an acceptable form of experiment in the accounting area [e.g. Holmes, Marriott, Randal 2012 or Libby, Bloomfield, Nelson 2002]. From that perspective such an experiment may provide insights into the overall perception of accounting assumptions, including the TFV principle. Experimental methods allow researchers to manipulate variables of interest as well as control negligible factors. Subsequently one can measure the intervening processes and mental states that affect the final outcomes [Greener 2008]. According to prior research, successful financial accounting experiments use the comparative advantages of the experimental approach to determine how, when and why important features of financial accounting settings influence behaviour [Bloomfield, Nelson 2002].

The author designed and conducted two experiments (experiment 1 and experiment 2). Experiment 1 consisted of conducting surveys among auditors between September and November 2012. First, the author solicited auditors attending local obligatory training courses designed for certified public auditors (CPAs). The anonymous questionnaire included only two open non-evaluative questions, which were designed in line to fundamental theory [Charmaz 2006]. The questions were: (1) 'What is truth in accounting for you?' and (2) 'Can one say that accounting reflects the truth? If not, please explain why'. Then, encouraged by the relatively high response rate ( 40 questionnaires received from the 41 participants), experiment I was extended onto further groups of auditors participating in the obligatory training. The results received from subsequent training courses were far fewer than those from the first CPA training (28 questionnaires of 320 CPAs). Nevertheless, the author finally received 68 responses from CPAs, And later executed the same survey among academics. The author selected 258 respondents representing the accounting departments of the most renowned universities, sending them (using dedicated anonymous e-mails) questionnaires, of which 26 were completed and returned [Piechocka-Kałużna 2014].

Based on the results from 94 questionnaires (68 from CPAs and 26 from academics) the author come to the unexpected conclusion that according to the respondents there is no truth in accounting. There was only 1 CPA who confirmed that accounting reflects the truth. The respondents' comments on the 'truth' in financial statements were then amplified through:

- individual intensive interviews with accountants (22 respondents) and auditors (20 respondents) and

- directed interview method which meant individual interviews with auditors (14 respondents) and group interviews with auditors (44 respondents) [Piechocka-Kałużna et al. 2015].

These interviews were originally devoted to implementing IFRSs and their perception related to truth in general, and to the TFV override in particular. The most 
frequently indicated reason was the potential opportunity (or rather risk) of misusing the sense of TFV. Summarizing the outcomes there appeared an unanticipated and sad conclusion that truth, in the eye of different groups of people associated somehow with financial reports, in fact does not exist.

Analysing the results received from experiment 1 as well as other research [Sikorska 2007], the author designed the experiment 2 that was conducted between September 2016 and March 2017. The key question stated during this second phase of research was whether participants accept the TFV override within accounting fundamental assumptions. The research sample for the second experiment consisted of 625 participants, included:

- 81 CPAs of which 32 was interviewed during the Christmas meeting and 49 during 2016 obligatory training sessions dedicated to CPAs,

- 428 accountants - interlocutors of telephone call encouraging for professional training for accounting firms,

- 116 undergraduate students of 'Finance and Accounting' interviewed using the directed interview method.

Table 1. Experiment 1 participants

\begin{tabular}{|c|c|c|c|}
\hline No & Type of research & Respondents & $\begin{array}{l}\text { Number } \\
\text { of respondents }\end{array}$ \\
\hline 1 & Intensive interviews: & & 42 \\
\hline 1.1 & $\begin{array}{l}\text { - individual interviews } \\
\text { with accountants }\end{array}$ & Accountants & 22 \\
\hline 1.2 & $\begin{array}{l}\text { - individual interviews } \\
\text { with auditors }\end{array}$ & Auditors & 20 \\
\hline 2 & Directed interviews: & & 58 \\
\hline 2.1 & $\begin{array}{l}\text { - individual interviews } \\
\text { with auditors }\end{array}$ & $\begin{array}{l}\text { Selected auditors attending the conference to } \\
\text { mark 20th anniversary of the Regional Branch } \\
\text { of the National Chamber of Statutory Auditors } \\
\text { in the Wielkopolska province }\end{array}$ & 14 \\
\hline 2.2 & $\begin{array}{l}\text { group interviews with } \\
\text { auditors }\end{array}$ & $\begin{array}{l}\text { Selected auditors participating in obligatory } \\
\text { training courses organised by the National } \\
\text { Chamber of Statutory Auditors in Poznan }\end{array}$ & 44 \\
\hline 3 & Questionnaires, including: & & 94 \\
\hline 3.1 & $\begin{array}{l}\text { - } \begin{array}{l}\text { completed by auditors } \\
\text { (paper questionnaire) }\end{array}\end{array}$ & $\begin{array}{l}\text { Auditors participating in obligatory training } \\
\text { organised by the National Chamber of } \\
\text { Statutory Auditors in Poznań }\end{array}$ & 68 \\
\hline 3.2 & 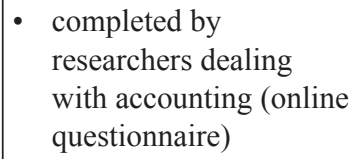 & $\begin{array}{l}\text { Researchers working in higher education } \\
\text { institutions }\end{array}$ & 26 \\
\hline
\end{tabular}

Source: own study based on research conducted between September and November 2012. 
Table 2. Experiment 2 - participants

\begin{tabular}{|c|c|c|c|c|c|c|}
\hline No & $\begin{array}{l}\text { Type of } \\
\text { research }\end{array}$ & Respondents & $\begin{array}{l}\text { Number of } \\
\text { respondents }\end{array}$ & $\begin{array}{c}\text { Number of } \\
\text { respondents } \\
\text { agreeing } \\
\text { TFV } \\
\text { override }\end{array}$ & $\begin{array}{c}\text { Number of } \\
\text { respondents } \\
\text { disagreeing } \\
\text { TFV } \\
\text { override }\end{array}$ & $\begin{array}{l}\text { Number of } \\
\text { respondents } \\
\text { who are } \\
\text { neutral }\end{array}$ \\
\hline 1 & $\begin{array}{l}\text { Directed } \\
\text { interviews: }\end{array}$ & & 625 & 66 & 450 & 109 \\
\hline 1.1 & $\begin{array}{l}\text { - individual } \\
\text { interviews } \\
\text { with } \\
\text { auditors }\end{array}$ & $\begin{array}{l}\text { Selected auditors } \\
\text { attending the } \\
\text { Christmas meeting } \\
\text { of the Regional } \\
\text { Branch of the } \\
\text { National Chamber of } \\
\text { Statutory Auditors } \\
\text { in the Wielkopolska } \\
\text { province }\end{array}$ & 32 & 3 & 27 & 2 \\
\hline 1.2 & $\begin{array}{l}\text { - individual } \\
\text { interviews } \\
\text { with } \\
\text { auditors }\end{array}$ & $\begin{array}{l}\text { Selected auditors } \\
\text { participating in } \\
\text { obligatory training } \\
\text { courses organised } \\
\text { by the National } \\
\text { Chamber of } \\
\text { Statutory Auditors in } \\
\text { Poznań } \\
\end{array}$ & 49 & 7 & 41 & 1 \\
\hline 1.3 & $\begin{array}{l}\text { - individual } \\
\text { interviews } \\
\text { with } \\
\text { accountants }\end{array}$ & $\begin{array}{l}\text { Accountants } \\
\text { interviewed during } \\
\text { telephone call } \\
\text { encouraging for } \\
\text { professional training } \\
\text { for accounting firms } \\
\end{array}$ & 428 & 17 & 317 & 94 \\
\hline 1.4. & $\begin{array}{l}\text { - individual } \\
\text { interviews } \\
\text { with } \\
\text { students }\end{array}$ & $\begin{array}{l}\text { Undergraduate } \\
\text { students of 'Finance } \\
\text { and Accounting' }\end{array}$ & 116 & 39 & 65 & 12 \\
\hline
\end{tabular}

Source: own study based on research conducted between September 2016 and March 2017.

The results show that there is strong opposition to TFV override in every set of experiment. Against the TFV override there were $83.9 \%$ CPAs, $74.1 \%$ accountants and $56.0 \%$ students. The problem is vital since in the eyes of those prearing and using financial statements there is a move in the direction opposite to truth. Such an opinion is confirmed by the rejection of the TFV assumption from IFRS Conceptual Frameworks. One may come to the conclusion that truth and TFV is not the key issue, which is definitely not a good trend, in the author's opinion. Although the EU implemented IFRS without the (controversial) Conceptual Framework this is not 
a solace. The IFRS usage is expanding rapidly all over the world and there is a threat that in the near future (with different lobbies' pressure) it will be relevance that completely replaces truth in financial statements. Such a possible change is neither necessary nor required. What is a financial statement without truth? Is it still relevant / useful? In the author's opinion, the answers to these two questions are obvious and indisputable. If any information included in financial statements is not true, it is not useful either, even if prepared under the dictate of investors. Besides, the role of science is approaching truth - not escaping from it.

\section{Conclusions}

Debates on the role of accounting and truth in accounting seem to be a "never ending story', ubt it does not mean they are not significant. These experiments systematised the comprehension of TFV as well as its meaning in the literature and the legal framework of accounting. Moreover the author identified, analysed and systematized the changes in the TFV importance's perception, as well as identified the trends in changes of TFV perception and its evaluation. The article also presents the conclusions of the proceedings to be finalised by normative guidelines.

Thanks to a literature review, the especially designed experiments and empirical analysis, the author obtained results that reveal interesting findings and should contribute to a discussion on truth in accounting. Those preparing and using financial statements expressed less willingness to accept current trends related to conceptual frameworks for accounting. They perceived a departure from emphasizing the importance of truth in financial statements as something notably negative. Therefore there is a need for a further discussion on the future development of accounting.

According to the studies, there is also noticeable trend towards a departure from TFV's application. Its existence and explanation is different for the EU as a whole and different for particular EU member states (like Poland). The reason in the case of the EU as a whole, is the implementation of IFRSs. The IFRSs themselves have changed and put more attention on relevance as one fundamental qualitative characteristic. According to the updated IFRS Conceptual Framework, relevant financial information is capable of making a difference in the decisions made by users. Information may be capable of making a difference in a decision, even if some users choose not to take advantage of it or are already aware of it from other sources.

In Poland the proven impression that legal requirements removed the truth from accounting is generated by two main reasons. Firstly, because accountants and auditors emphasize that being based only on TFV may be an area for potential abuse. Such risk mostly leads to distortions in financial statements, and financial statements that encompass distortions definitely must not be perceived as documents providing truth to recipients. Secondly, according to the research, accountants and auditors do not accept their responsibility for indistinct rules. They would expect clear guidelines in return, guidelines that could replace their professional judgement based on the TFV concept override. 
This paper proved the devaluation in the TFV concept in accounting (including reporting), which is particularly evident in IFRS regulation and literature after 2010. Especially after 2010, we can see the transfer of emphasis from the truth to the usefulness of financial reporting and the devaluation of the precautionary principle. According to the author's opinion, this trend is unfavourable, and independently of the procedure of practitioners in this field, or whether constituting the law, the role of science is to uphold these fundamental values and indicate the correct way to truth, not allowing ourselves to become embroiled in particular interests of any pressure groups. One can indicate the transfer of emphasis from the truth towards the usefulness of financial reporting, as well as on the devaluation of the principle of prudence. In the author's opinion, this trend is unfavourable and the role of science is to uphold these fundamental values and indicate the correct way to truth, not allowing to become embroiled in particular interests of any group of interest.

The conclusions stated above have significant repercussions on accounting in general, and reporting in particular, in every country, especially the EU member states such as Poland. Changes of the role and perception of TFV is observable through the revision of accounting regulations. One must remember that every EU member is required to implement relevant regulations into its own (local) legal environment. It is Directive 2013/34/EU that has guidelines for a country's accounting act. On the other hand, according to EU regulations there are some entities (at least those quoted on European stock exchanges) for which the preparation of financial statements under IFRSs is mandatory.

The results of this study contribute to the discussion on truth in accounting and on the justification for the TFV's assumption in accounting. These conclusions are subject to common limitations of experimental research. The author questioned mostly professionals and their judgments on truth in accounting, therefore the conclusions may not apply to non-professionals and other financial statement users. Future research could examine the consequences of the changing role of TFV on other parties.

\section{Bibliography}

Accounting Principle Board's (APB) Statement no. 4, Basic Concepts and Accounting Principles Underlying Financial Statements of Business Enterprises.

Ajdukiewicz K., 1983, Zagadnienia i kierunki filozofii. Teoria poznania. Metafizyka, Czytelnik, Warszawa.

Ajdukiewicz K., 2004, Zagadnienia i kierunki filozofii. Teoria poznania. Metafizyka, Antyk - Fundacja Aletheia, Warszawa.

Alexander D., Jermakowicz E., 2006, A True and Fair View of the Principles/ Rules Debate, ABACUS, vol. 42, no. 2, 2006.

Aristotle, Metaphysics (Translated by W.D. Ross), 2015, The University of Adelaide, https://ebooks. adelaide.edu.au/a/aristotle/metaphysics/index.html. 
Austin, J.L., 1950, Truth, reprinted in Philosophical Papers, 3rd ed., Oxford University Press, Oxford 1979, pp.117-33.

Bloomfield R., Nelson M.W., 2002, Experimental research in financial accounting, Accounting, Organizations and Society, vol. 27, issue 8, pp. 775-810.

Byrne G., 1937, To what extent can the practice of accounting be reduced to rules and standards, Journal of Accountancy, November, pp. 346-379.

Charmaz K., 2006, Constructing Grounded Theory. A Practical Guide through Qualitative Analysis, Sage Publications.

David M., 1994, Correspondence and Disquotation: An Essay on the Nature of Truth, Oxford University Press, Oxford.

Davidson D., 1990, The structure and content of truth, The Journal of Philosophy, vol. 87, no. 6, Jun., pp. 279-328.

Directive 2013/34/EU on the annual financial statements, consolidated financial statements and related reports of certain types of undertakings.

FASB, Statement of Financial Accounting Concepts No. 2, Qualitative Characteristics of Accounting Information.

Financial Reporting Council, 2014, True and fair, https://www.frc.org.uk/FRC-Documents/Accounting-and-Reporting/True-and-Fair-June-2014.pdf.

Flower J., 2004, European Financial Reporting: Adapting to a Changing World, Palgrave.

Fourth Council Directive 78/660/EEC of 25 July 1978 based on Article 54(3)(g) of the Treaty on the annual accounts of certain types of companies superseded by Directive 2013/34/EU on annual and consolidated financial statements and related reports.

Greener S., 2008, Business Research Methods, Ventus Publishing.

Hendriksen E.S., van Breda M.F., 1992, Accounting Theory, 5th Edition, Irwin.

Holmes K., Marriott L., Randal J., 2012, Ethics and experiments in accounting: A contribution to the debate on measuring ethical behaviour, Pacific Accounting Review, vol. 24, issue 1, pp. 80-100.

International Financial Reporting Standards, International Accounting Standards Board.

Keuth H., 2005, The Philosophy of Karl Popper, Cambridge University Press.

Kirkham R.L., 1992, Theories of Truth: A Critical Introduction, MIT Press, Cambridge, Mass.

Kotarbiński T., 1961, Elementy teorii poznania, logiki formalnej i metodologii nauk, Zakład Narodowy Imienia Ossolińskich - Wydawnictwo, Wrocław-Warszawa-Kraków.

Künne W., 2003, Conceptions of Truth, Clarendon Press, Oxford.

Libby R., Bloomfield R., Nelson M.W., 2002, Experimental research in financial accounting, Accounting, Organizations and Society, 27, pp. 775-810.

May G., 1937, Principle of accounting, Journal of Accountancy, December, pp. 423-425.

Milanov E., 2002, Implementation of the True and Fair View Legal Requirement for Financial Reporting in Some Prospective EU Members, in Beyond Boundaries: Challenges of Leadership, Innovation, Integration, and Technology, International Conference of the Global Business and Technology Association, Rome, 25-29 June.

Moonitz M., 1961, The basic postulates of accounting, Accounting Research Study, no. 1.

New Webster's Dictionary and Thesaurus of the English Language 1972/1993.

Nobes C., 2000, Is true and fair of overriding importance? A comment on Alexander's benchmark, Accounting and Business Research, vol. 30, no. 4.

Nobes C., Stadler C., 2014, The qualitative characteristics of financial information, and managers' accounting decisions: Evidence from IFRS policy changes, IFRS Research Forum.

Nolan J., 1972, Wheat study members assess product, Journal of Accountancy, June.

Piechocka-Kałużna A., 2014, Wykorzystanie metody teorii ugruntowanej w nauce rachunkowości na przykładzie badań nad prawda w sprawozdawczości finansowej, Wydawnictwo Uniwersytetu Ekonomicznego w Poznaniu, Poznań. 
Piechocka-Kałużna A., Kałużny R., Matuszak Ł., Garstecki D., 2015, IFRS regulations and its' impact on comparability and relevance of financial statements in light of K.R. Popper's methodologyempirical study, paper under review.

Popkin R.H., Stroll A., 1993, Philosophy made simple, 2nd Edition revised, Doubleday.

Popper K., 1972, Objective Knowledge: An Evolutionary Approach. Oxford University Press, USA

Putnam H., 1981, Reason, Truth and History, Cambridge University Press.

Rescher N., 1973, The Coherence Theory of Truth, Oxford.

Schipper K., 2005, The introduction of International Accounting Standards in Europe: Implications for international convergence, European Accounting Review, vol. 14, no. 1.

Seidler L.J., 1984, No accounting of FASB's draft on recognition and measurement, Accounting Issues, April.

Sikorska M., 2007, True and fair view w teorii i praktyce polskiej rachunkowości, Zeszyty Teoretyczne Rachunkowości, vol. 38, nr 94, pp. 205-214.

Smid J., 2014, Tarski's one and only concept of truth, Synthese, vol. 191, issue 14, pp. 3393-3406.

Sprouse R., Moonitz M., 1962, A tentative set of broad accounting principles, Accounting Research Study, no. 3.

Tarski A., 1933, Pojęcie prawdy w językach nauk dedukcyjnych, Warszawa.

Tarski A., 1949, The semantic conception of truth, [in:] Feigl H., Sellers W. (eds.), Readings in Philosophical Analysis, New York.

Tarski A., 1970, Truth and proof, [in:] Hanfling O. (ed.), Fundamental Problems in Philosophy, Oxford.

The AICPA SAS 69, 1992, The Meaning of 'Present Fairly' in Conformity with Generally Accepted Accounting Principles.

Tichy P., 1974, On Popper's definitions of verisimilitude, The British Journal for the Philosophy of Science, vol. 25, no. 2 (Jun.), pp. 155-160.

van Hulle K., 1997, The True and Fair Override in the European Accounting Directives, European Accounting Review, vol. 6, no. 4.

Whittington G., 2005, The adoption of International Accounting Standards in the European Union, European Accounting Review, vol. 14, no. 1.

\section{EWOLUCJA ZNACZENIA ZASADY WIERNEGO I RZETELNEGO OBRAZU NA PRZYKLADZIE POLSKI}

Streszczenie: Celem artykułu jest zagadnienie prawdy, która jest nierozerwalnie związana z rachunkowością (i w związku z tym ze sprawozdawczością, jako jej częścią) i jest odzwierciedlona w zasadzie wiernego i rzetelnego obrazu. Artykuł ukazuje istotę i ewolucję zasady wiernego i rzetelnego obrazu oraz wskazuje na jej rolę wśród zestawu cech jakościowych sprawozdania finansowego. Po dokonaniu analizy zmian w sposobie postrzegania tej zasady, w artykule znajduje się krytyczna ocena oraz wkład w postacie wskazówek dla stanowiących prawo w tym standardy sprawozdawczości. Uwzględniając ograniczenia typowe dla badań behawioralnych w artykule znajdują się praktyczne i społeczne implikacje wraz ze wskazaniem jak zasada wiernego i rzetelnego obrazu wpływa na odbiorców sprawozdań finansowych, jak i na osoby je sporządzające.

Słowa kluczowe: zasada wiernego i rzetelnego obrazu, prawda w rachunkowości, prawda w sprawozdawczości, cechy jakościowe sprawozdań finansowych. 